\title{
27. GAMMA-RAY WELL-LOG CHARACTERISTICS, LEG 96 ${ }^{1}$
}

\author{
J. M. Coleman, Louisiana State University \\ R. Constans, Chevron U.S.A. Inc \\ and
}

A. H. Bouma, Gulf Research and Development Co. ${ }^{2}$

\begin{abstract}
Gamma-ray well-log traces from six sites on the Mississippi Fan visited during Deep Sea Drilling Project (DSDP) Leg 96 were processed by Chevron's NFLECT program ${ }^{3}$ to provide data on grain-size trends and bedding thickness, in addition to the common evaluation of lithologies of missed cored sections.

The midfan channel sites (621 and 622) and the lower fan channel site (623) contain the highest percentage of gamma-ray NFLECT-calculated "sand." Site 623 contains the highest percentage of gamma-ray NFLECT "silt" of all sites, and the lower fan overbank site (624), the highest percentage of "clay." The lower fan distal site (615) contains less than $10 \%$ gamma-ray NFLECT sand but is very high in silt.
\end{abstract}

\section{INTRODUCTION}

During DSDP Leg 96, open-hole logging runs were made using Schlumberger wireline sondes at six sites $(615$, $620,621,622,623$, and 624) on the Mississippi Fan. In addition, Site 616 was logged through the drill pipe with a combined formation density/compensated neutron/ gamma-ray tool. The site locations and types of logs run are shown in Figure 1. The data recorded from these runs fill in missing information between the recovered core data and aid in the interpretation of the sedimentary sequences deposited in the youngest fan lobe of the Mississippi Fan.

The theoretical principles and applications of the various logging tools used on this leg are summarized in Schlumberger log interpretation manuals (Schlumberger, 1972, 1974). Factors affecting log responses and the fundamentals of log evaluation are also presented by Asquith and Gibson (1982) and Helander (1983).

The configuration of the drilling operations on the Glomar Challenger and the unconsolidated nature of the shallow sediments penetrated presented a rather hostile environment for wireline electric logging. Only small-diameter logging tools could be employed because the absence of a drilling riser system mandated that all tools be lowered through drill pipe into open hole. Use of seawater as a drilling fluid rather than a mud system also contributed to the less than optimum logging conditions. Large washout zones and bridging of the borehole by soft sediments hampered logging operations and raised questions as to the validity of some of the density and porosity measurements. Details of the logging operations,

\footnotetext{
${ }^{1}$ Bouma, A. H., Coleman, J. M., Meyer, A. W., et al., Init. Repts. DSDP, 96: Washington (U.S. Govt. Printing Office).

2 Addresses: (Coleman) Coastal Studies Institute, Louisiana State University, Baton Rouge, LA 70803; (Constans) Chevron USA Inc., 935 Gravier St., New Orleans, LA 70112; (Bouma, present address) Chevron Oil Field Research Co., P.O. Box 36506, Houston, TX 77236.

${ }^{3}$ Chevron's NFLECT program was specifically designed for another well-log trace, but has been adapted to gamma-ray traces for this study. The technical justification for such adaptation to gamma-ray traces has not been worked out completely and may pose questions in hin-bed corrections.
}

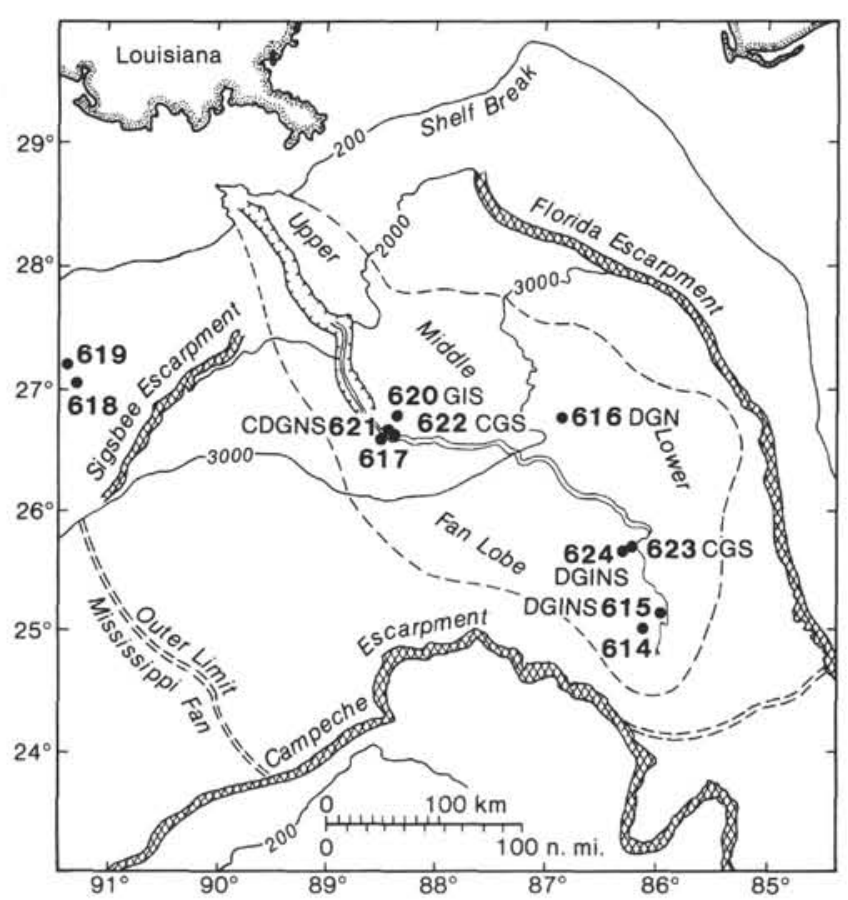

Figure 1. Location of Mississippi Fan sites drilled on DSDP Leg 96 with indications of the types of well logs run. $\mathrm{C}=$ caliper log, D $=$ formation density $\log , \mathrm{G}=$ gamma-ray $\log , \mathrm{I}=$ dual-induction lateral $\log , \mathrm{N}=$ compensated neutron $\log , \mathrm{S}=$ long-spaced sonic $\log$.

hole conditions encountered, and tool failures at each of the logged sites can be found in the operations section of the site summaries (this volume).

The porosity values calculated from the density tools generally range from 50 to $60 \%$. Although these values appear to be in agreement with the porosity values calculated from physical-property studies (see Bryant, Wetzel, Taylor, and Sweet, this volume) and the measured porosities from sedimentologic studies of core slabs (see Coleman, Bouma, et al., this volume), the reliability of the log porosity data is questionable because of the large 
variations in the log curves. Therefore, density and porosity characteristics from the logs will not be discussed in this chapter.

The gamma-ray log was used as the primary lithology $\log$ because of the lack of a diagnostic signature recorded on the spontaneous potential log (SP). The gamma-ray tool is a device that consists of a scintillation-type detector that measures natural background gamma-ray emissions. These emissions are usually caused by decay of potassium, thorium, and uranium salts present in sands and shales. Shales, particularly marine shales, have a greater gamma-ray emission level than sandstones, limestones, and dolomites (Helander, 1983). This difference makes the gamma-ray tool useful for distinguishing shales from nonshales. Slight variations in the diameter of the borehole do not appreciably affect the gamma-ray response, but large washout zones may cause a slight decrease in the gamma-ray count. Caution must be employed, therefore, when using the gamma-ray log as a lithologic indicator in extremely washed out boreholes. The caved-in zones identified from the caliper log appear to correlate with sandy cored intervals in the Mississippi Fan sites logged with the gamma-ray tool. The lowering of gamma-ray counts in these zones by borehole conditions serves principally as positive reinforcement of the interpretation of a sandy lithology.

Gamma-ray logging through drill pipe can reduce the gamma-ray radioactivity by as much as $30 \%$. Although a log with good diagnostic character was recorded through drill pipe at Site 616, the reduced values are not readily comparable with the sites logged in open hole. Therefore, Site 616 logging results are not discussed here.

\section{METHODS}

The gamma-ray data were processed utilizing one of Chevron Geosciences' computer well-log applications. The purpose of this particular program (NFLECT) is to develop a trace that sharply defines bed boundaries and reflects a truer value of the static spontaneous potential (SP) independent of layering effects. This is done by measuring the amount and rate of change on the trace and by specifying thresholds that cause the trace to be reset to some specified value if those thresholds are exceeded.

The computer processing of the gamma-ray data was executed in the following manner: Data from the field tapes were transferred to disks accessible by an IBM mainframe computer. The data were recorded on tape in feet and had to be converted to meters. The integrity of these data was checked by playing back the digits and matching them to the logs. After removing baseline drift, the gamma-ray trace was "smoothed" using a 3-ft. running average window to filter out high-frequency information that is noise and not related to bedding sequence. The values of this trace were then inverted to simulate the response of an SP trace. The NFLECT program was run over this trace to produce the "squared" gamma-ray NFLECT trace. Beds that are not significant in a statistical sense are suppressed by the choice of suitable parameters. The same parameters were used at all sites to insure consistent interpretations.

A typical section of traces generated with these procedures is displayed in Figure 2. The inflection trace was used with liberal limits to predict relative lithology. Gamma-ray values greater than 70 API indicate coarse sediments; values less than 20 API indicate fine sediments. The broad range of values that falls between these limits is considered either intermediate or mixed.

The NFLECT program was used to classify the log response into the three categories described above on a $0.2-\mathrm{m}$ interval, and thus log thickness could be obtained for each category in the hole. This capability permits evaluation of the bedding-thickness variation in a vertical sense. In addition, the program sums up the categories over $10-\mathrm{m}$

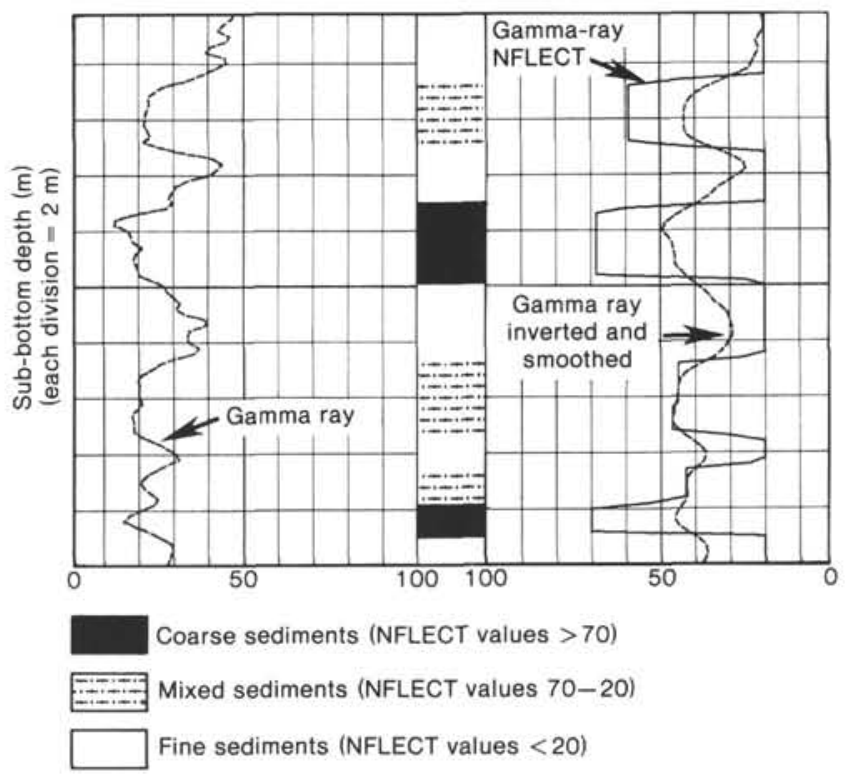

Figure 2. Key to gamma-ray and gamma-ray NFLECT curves.

range, allowing an evaluation of the vertical change in grain-size distribution. The gamma logs also allow an evaluation of the sharpness of the bedding planes and shape of the intervals. These characteristics of each logged hole are discussed later.

\section{NFLECT ZONES AND LITHOLOGIC INTERPRETATIONS}

The gamma-ray NFLECT values were compared to core photographs and descriptions and to various sedimentological analyses that were conducted by shore-based scientists to obtain a better understanding of the relationship between the NFLECT values and the sedimentology of the deposits at each site. It must be remembered, however, that the logged intervals do not represent the entire cored interval because of surface pipe and occasional inability of the logging tool to penetrate to the bottom of the open hole. It is, therefore, often difficult to correlate core recovery depth precisely with logging depth. For this reason, only core samples that fell into large intervals of continuous NFLECT data were used to determine the characteristics of the gamma-ray response.

\section{NFLECT Values $>70$ API (coarse sediments)}

The average of 18 samples recovered from intervals in this NFLECT category contain $65 \%$ sand, $30 \%$ silt, and $5 \%$ clay. One sample contained $95 \%$ sand, $5 \%$ silt, and $0 \%$ clay, the average grain size being in the medium sand range. The finest grained samples generally consist of $35 \%$ sand, $55 \%$ silt, and $10 \%$ clay. These grain size and mineralogical results indicate that sediments in this NFLECT category consist of relatively clean sands containing scattered redeposited organics and mica.

On the core photographs and X-ray radiographs the sands appear massive and display little or no internal structure. It has proven impossible, however, to determine whether this lack of internal structure is a result of the coring disturbance or natural. A crude size grading 
is apparent in some cores; in a few instances, radiographs indicate small-scale cross-laminations in finer grained layers within the overall sandy unit. The sands also contain a few very thin clay laminations (generally less than a few centimeters thick, although one sand had a clay layer $8 \mathrm{~cm}$ thick). Another sample, displaying thin silty clay laminations alternating with graded sand layers, was tilted at an angle of $20^{\circ}$.

Porosity measurements within these NFLECT values were rare, but values of 29 and $35.4 \%$ were recorded in two samples from shipboard measurements. Roberts and Thayer (1985) indicate that, in measurements on 50 thin sections of which only 20 fell within this NFLECT interval, porosity ranges from 20 to $35 \%$. Estimates based on the size and sorting indicate that an additional 26 samples have porosities that range from 30 to $49 \%$ (Thayer et al., this volume). These samples were moderately well to well sorted. The massive nature of the sands, the relatively high porosities, moderately well to well sorting, and lack of substantial clay content are probably characteristic of this NFLECT interval.

\section{NFLECT Values 70 to 20 API (mixed sediments)}

The 70 to 20 NFLECT interval represents those sediments that fall between the finer grained clays and the coarser sands. As expected, a wide variation in properties was found. Textural averages of samples from this interval are $23 \%$ sand, $51 \%$ silt, and $26 \%$ clay. Sand content ranges as high as $69 \%$ and as low as $3 \%$; clay values range from 1 to $67 \%$. This unit is composed primarily of alternating thin sands and clays with abundant finely laminated silts. Thin, graded laminae, only a few millimeters to a few centimeters thick, are the most common structures. The sand laminations rarely exceed $15 \mathrm{~cm}$ in thickness, whereas the silt layers commonly range up to $20-25 \mathrm{~cm}$ thick. Mica and redeposited woody organic material are common in the silt and fine-sand units (see site chapters, this volume). Thin-section analyses by Roberts and Thayer (1985) show that the sands range from fine to very fine in grain size, are moderately well sorted, and have porosities that range from 25 to $41 \%$ and permeabilities that range from 0.5 to 8.0 darcies. Thus, this NFLECT interval represents the siltier thin-bedded sediments.

\section{NFLECT Values <20 API (fine sediments)}

The $<20$ NFLECT unit represents the finest grained sediments present in the recovered cores. Average textural values, based on 22 samples, are $2 \%$ sand, $45 \%$ silt, and $53 \%$ clay. Sand content ranges as high as $10 \%$, but many samples contained no sand-sized particles. Clay content ranges from a high of $80 \%$ to a low of $40 \%$. The samples display one of two major types of stratification: either extremely thin-laminated silts and clays or relatively thick-bedded ( 40 to $80 \mathrm{~cm}$ ) clays. Disturbed structures such as microfracturing and thin convolute laminations are very common within this unit.

Although the NFLECT values do not necessarily correlate specifically with grain-size intervals, NFLECT values greater than 70 represent the well-sorted coarser sequences and, for convenience, these deposits are referred to as "sands." NFLECT values less than 20 represent the finest-grained sediments, and they are referred to as "clays." Sediments with NFLECT values ranging from 70 to 20 are referred to as "silts."

\section{NFLECT CHARACTERISTICS}

\section{Sites 621 and 622}

Holes 621 and 622 were drilled in the midfan channel, Hole 621 in the thalweg of the channel and Hole 622 on the inside concave or "point bar" side of the channel (Site 621 and 622 chapters, this volume). Figure 3 illustrates typical gamma-ray log responses of the sediments in these two holes. The uppermost sediments were not logged because of pipe in the hole, and thus the finer-grained "passive fill" of the channel is not well represented. The overall log response at both sites shows a fining-upward sequence, with gamma counts ranging from a high of 90 API units (NFLECT value of 10) near the top of the holes to a low of 30 API units (NFLECT value of 70) near the bottom. Most of the coarser-grained intervals exhibit a blocky shape, with sharp bases and sharp tops. Most of the sands are both underlain and overlain by clays.

Figure 4 illustrates the bedding-thickness variation for each NFLECT interval at Site 621. With one exception at $90 \mathrm{~m}$ sub-bottom, the "sand" beds thin upward, especially when combined with the uppermost unlogged intervals (Fig. 4A). Sand beds average $1.44 \mathrm{~m}$ in thickness (standard deviation 0.4 ). The silt beds do not show any particular trend and average $2.26 \mathrm{~m}$ in thickness with a standard deviation (SD) of 1.54 (Fig. 4B). Near the top of the hole there is some indication that packages of thickening-upward sequences exist, each package 12 to $15 \mathrm{~m}$ thick. The clay intervals thicken upward from the base of the hole to a sub-bottom depth of 140 $\mathrm{m}$ and then thin upward to the top of the hole (Fig. 4C). Clay beds average $2.05 \mathrm{~m}$ in thickness, with a standard deviation of 1.29 .

Grain-size trends at Site 621 were averaged over 10-m increments (Fig. 5). Within the logged interval, no apparent trend is present within the sand- or silt-sized units. However, it must be remembered that the uppermost finegrained unit at the top of the borehole was not logged. Clay percentages show a persistent increase uphole to $124 \mathrm{~m}$ sub-bottom and then a rather dramatic decrease to the top of the logged interval.

Figures 6 and 7 illustrate generally the same bed thickness and textural characteristics for Site 622 as were observed at Site 621, except that the vertical variations in grain size are not quite as apparent. Sand beds average $1.13 \mathrm{~m}$ in thickness (SD 0.29), silt and clay beds $1.90 \mathrm{~m}$ (SD 1.29) and $1.44 \mathrm{~m}$ (SD 0.64), respectively.

\section{Site 620}

Hole 620 was drilled approximately $18 \mathrm{~km}$ east of the midfan channel and generally contains sediments that were deposited in an overbank environment (see Site 620 chapter, this volume; Fig. 1). The gamma-ray log response is shown in Figure 8, and analysis of the log indicates that it is generally a silt-rich sequence, containing only 
J. M. COLEMAN, R. CONSTANS, A. H. BOUMA

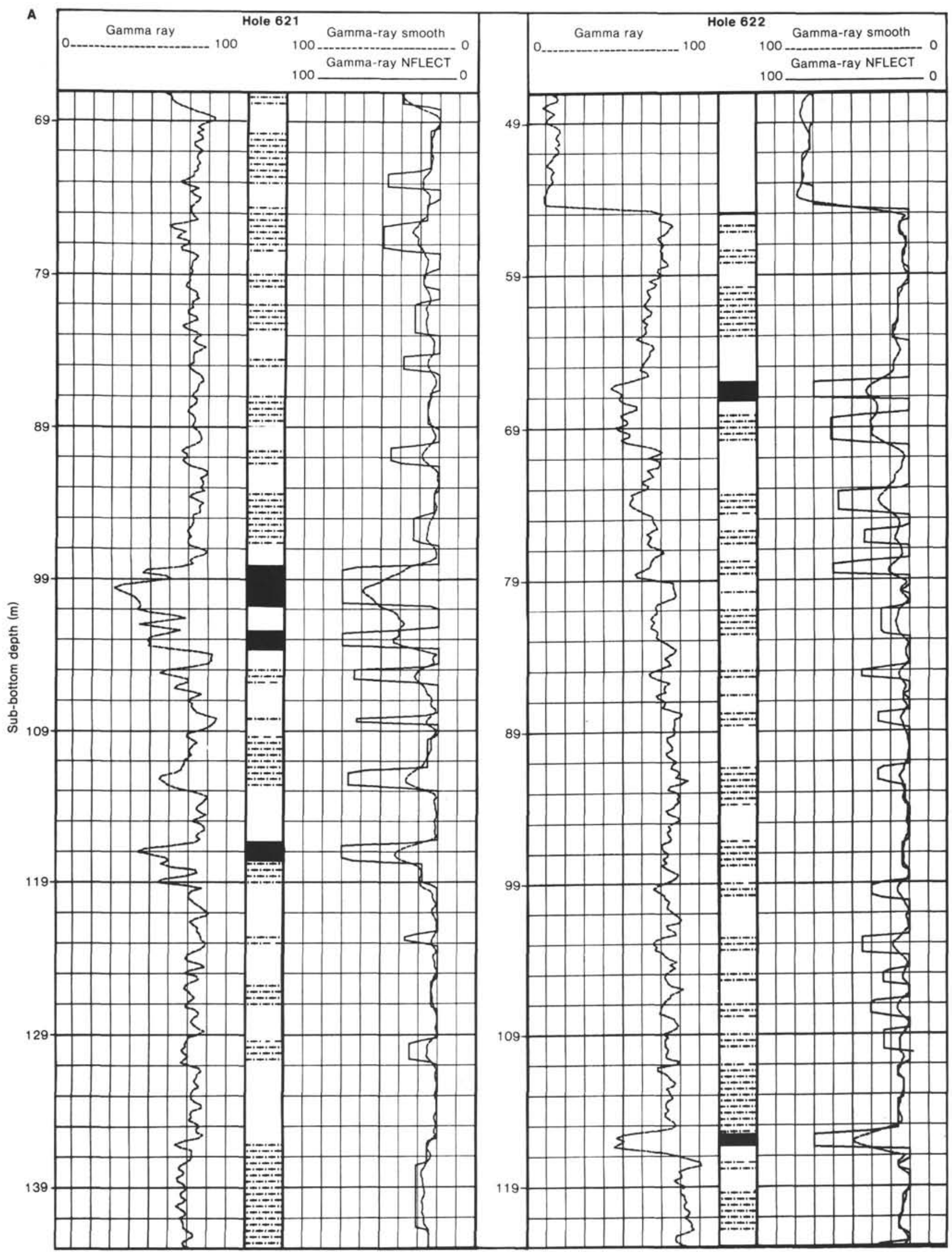

Figure 3. Gamma-ray and gamma-ray NFLECT curves for (A) upper and (B) lower parts of Sites 621 and 622 . Key to lithology symbols is given in Figure 2. Depths in this figure, and in all other figures in this chapter, are in meters below seafloor converted from PDR depths originally recorded on logs. 
GAMMA-RAY WELL-LOG CHARACTERISTICS

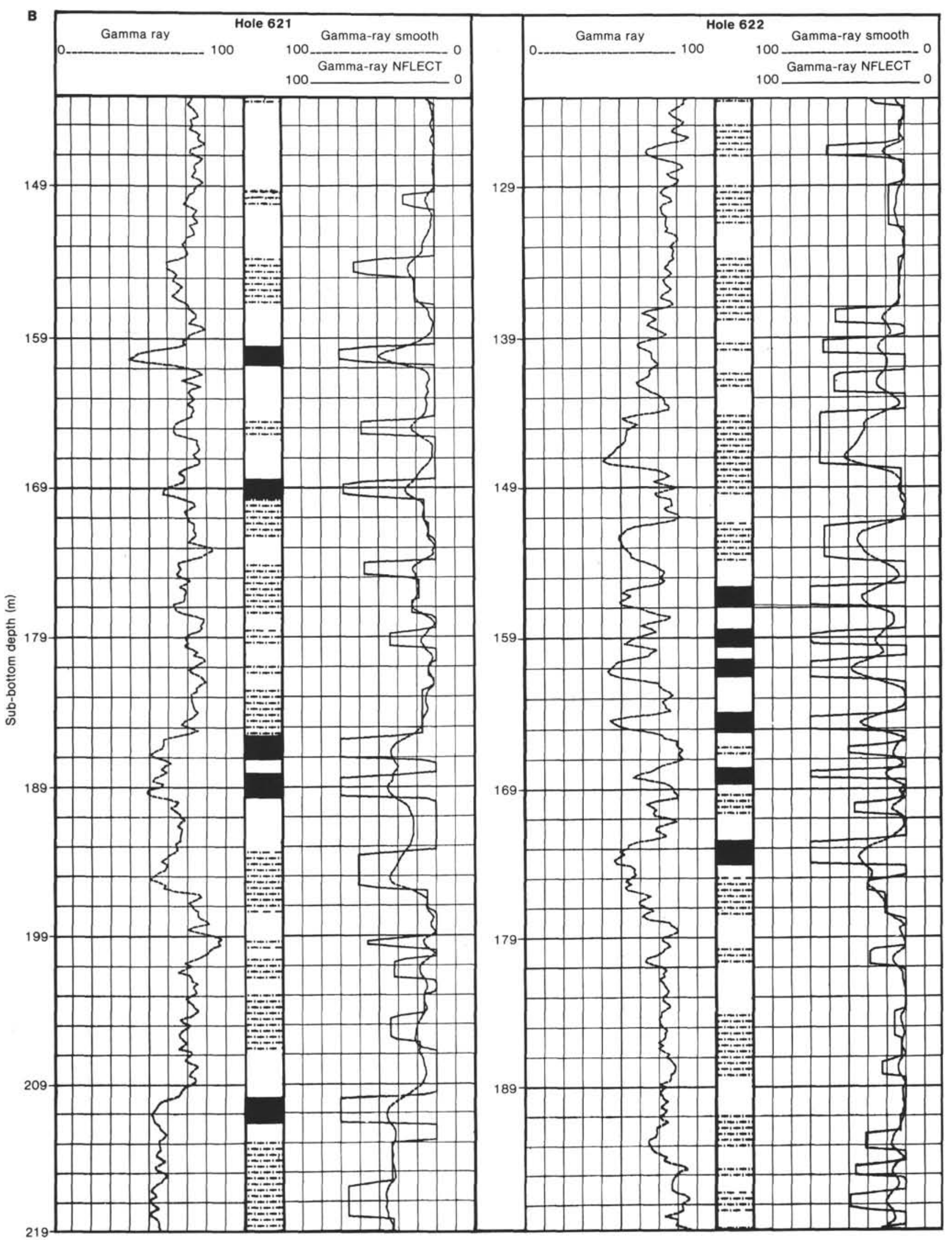

Figure 3 (continued). 

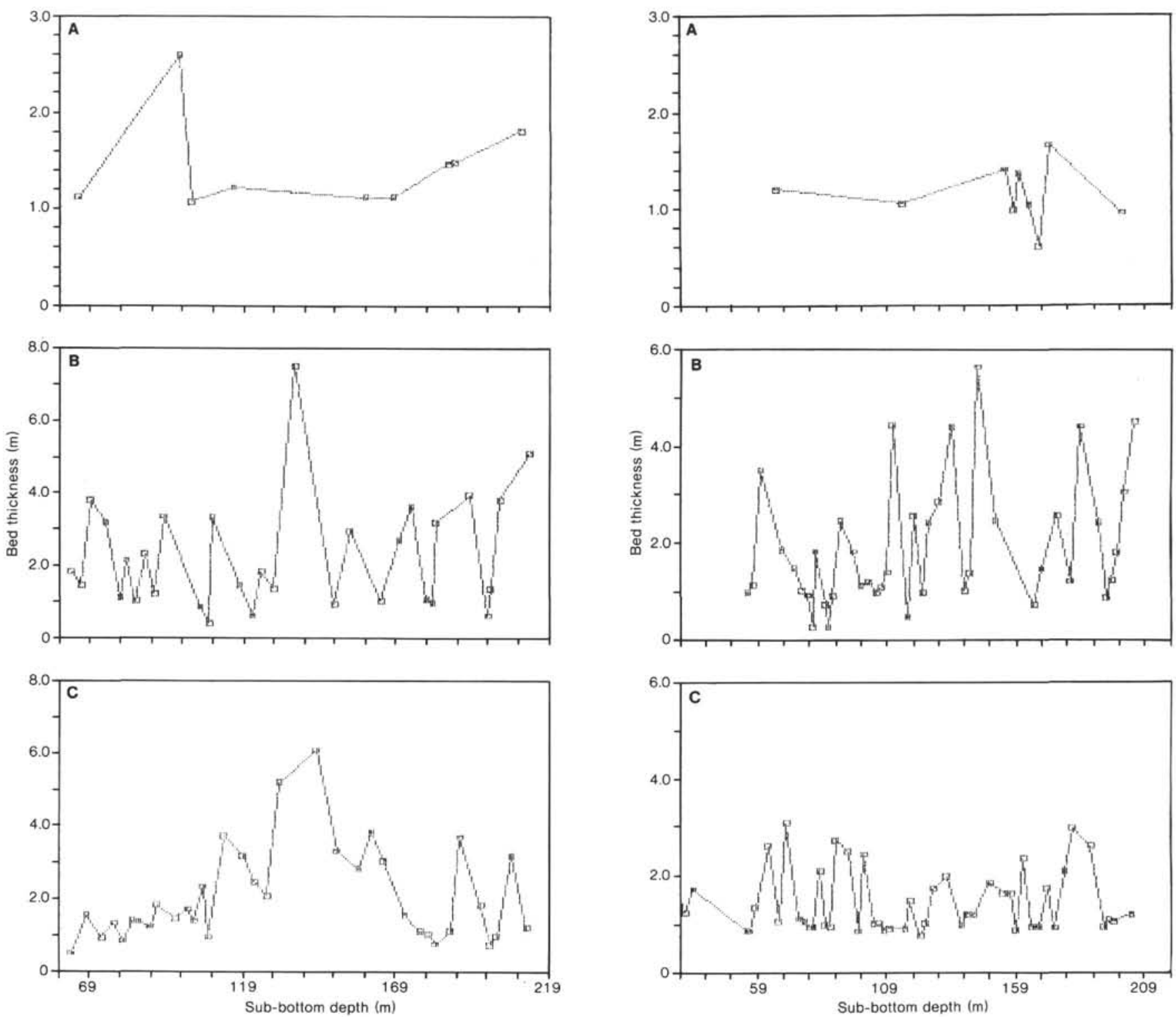

Figure 4. Bed-thickness trends of (A) sand (NFLECT >70 API), (B) silt (NFLECT 70-20 API), and (C) clay (NFLECT $<20 \mathrm{API})$ at Site 621 .

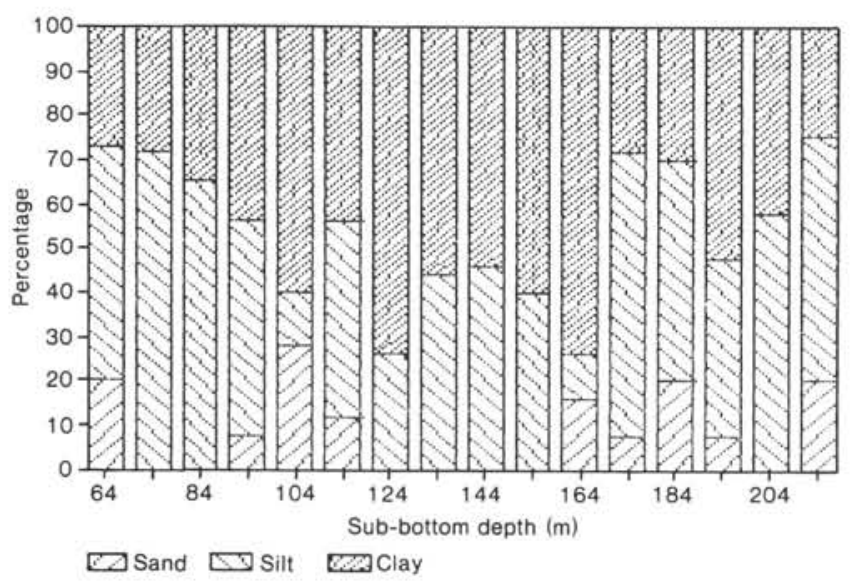

Figure 5. Sand-silt-clay percentages averaged over 10 -m increments at Site 621 . 
GAMMA-RAY WELL-LOG CHARACTERISTICS

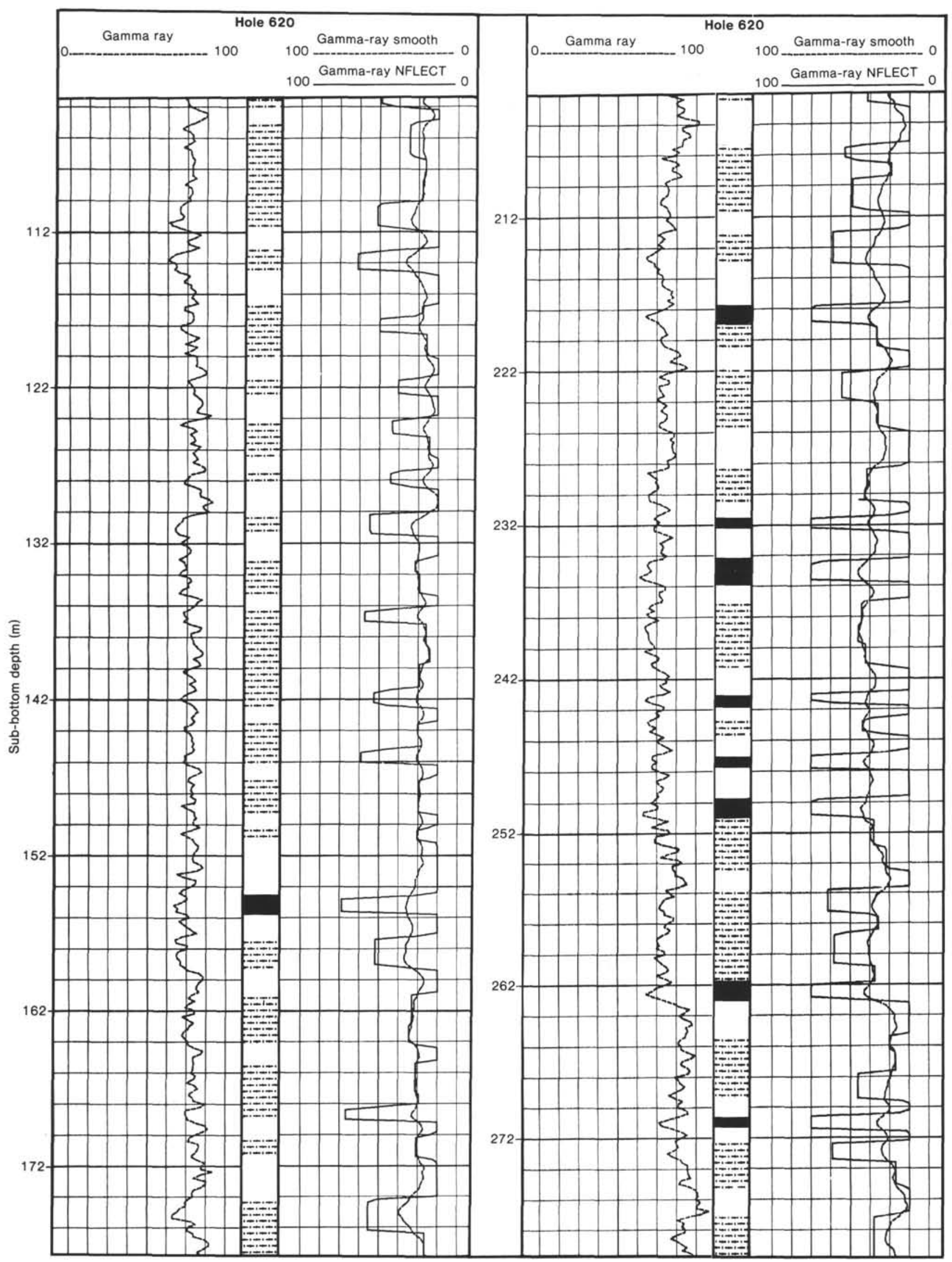

Figure 8. Gamma-ray and gamma-ray NFLECT curves for Site 620. Key to lithology symbols is given in Figure 2. 
thin sand and clay intervals. Bedding thicknesses in all three NFLECT intervals show no trends (Fig. 9). The sand beds average $0.98 \mathrm{~m}$ in thickness (SD 0.30), clay beds average $1.46 \mathrm{~m}$ (SD 0.62); the thickest beds are silt, averaging $2.83 \mathrm{~m}$ (SD 1.54). In a general sense, the silt beds appear thickest near the top of the borehole. Grainsize trends illustrate that the silt percentage increases upward and that most of the sand is located near the bottom of the hole (Fig. 10).

\section{Site 623}

Hole 623 was drilled in the lower fan in a channeloverbank complex (Fig. 1; see Site 623 chapter, this volume). In this region of the lower fan, only a single small channel appears to be active at any one time, and adjacent to it numerous abandoned channels are present (Low-
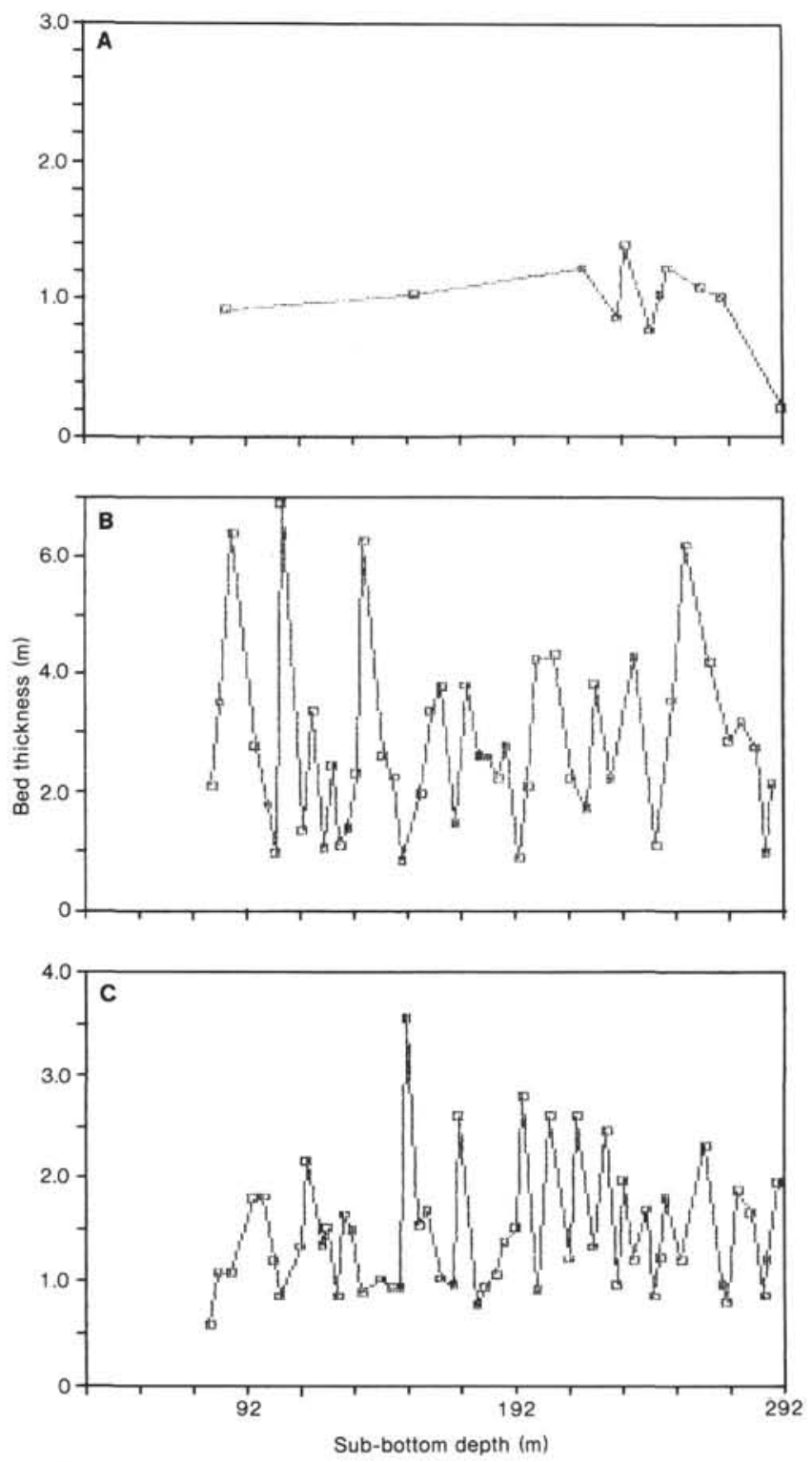

Figure 9. Bed thickness trends of (A) sand (NFLECT >70 API), (B) silt (NFLECT $70-20 \mathrm{API})$, and (C) clay (NFLECT $<20 \mathrm{API})$ at Site 620 .

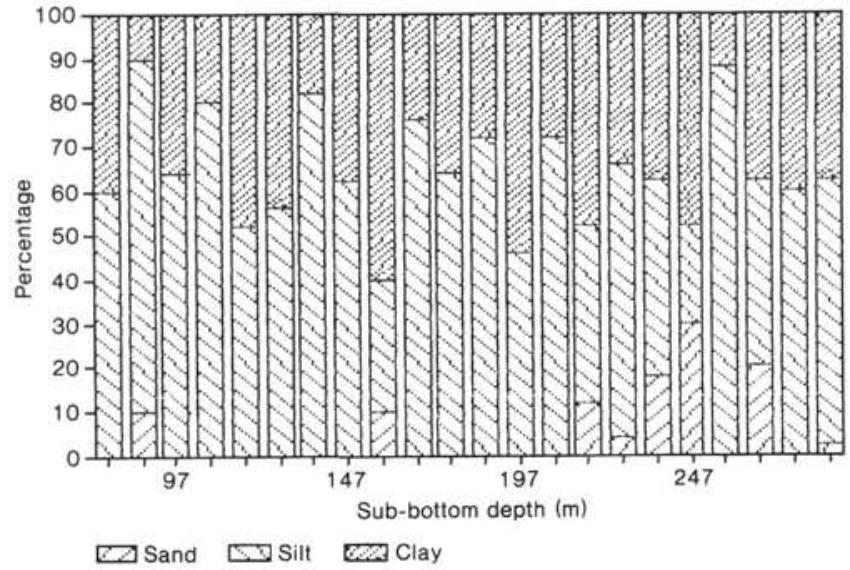

Figure 10. Sand-silt-clay percentages averaged over $10-\mathrm{m}$ increments at Site 620 .

er Fan Introduction and Summary, this volume). Thin packages of sand tend to be overlain by silt and then clay, each package being 15 to $20 \mathrm{~m}$ thick (Fig. 11). The sands are all underlain by clays and are capped by rather thick-bedded silts. The sand beds average $1.48 \mathrm{~m}$ in thickness (SD 0.47); the silt beds show a high variability in thickness, averaging $2.71 \mathrm{~m}$, but have a standard deviation of 3.52 (Fig. 12). Clay beds are thinner, averaging only $1.25 \mathrm{~m}$ in thickness, and show a low standard deviation (0.49). Grain-size percentages averaged at $10-\mathrm{m}$ intervals show the fining-upward packages that are characteristic of these sediments (Fig. 13).

\section{Site 624}

Site 624 is located west of Site 623 in an area removed from the channel-overbank complex (Fig. 1; Site 624 chapter, this volume). This site displays the finest grained sediments of all the wells logged, containing only $1.4 \mathrm{~m}$ of net sand, $31.6 \mathrm{~m}$ of net silt, and $92.0 \mathrm{~m}$ of net clay over the logged interval of $125 \mathrm{~m}$. Figure 11 illustrates an example of the gamma-ray response at Site 624; note that, with the exception of the single thin sand, the response is extremely spiked, indicative of alternating silt and clay layers. The thick-bedded nature of the layering is illustrated by Figure 14; the average silt layer is $3.49 \mathrm{~m}$ thick (SD 3.08) and the average clay layer is $9.51 \mathrm{~m}$ thick (SD 9.94). The grain-size trend appears to fine upward to a sub-bottom depth of $102 \mathrm{~m}$; above that level, a slight coarsening-upward trend is suggested (Fig. 15).

\section{Site 615}

Hole 615 was the deepest hole drilled on Leg 96 and was located on the lower fan near the termination of the channel at its distal end (Fig. 1). Two fan lobes were encountered at the site (see Site 615 chapter, this volume). At a sub-bottom depth of $242 \mathrm{~m}$, a prominent seismic horizon occurs that separates these two fan lobes; it is also at this point that an increase in planktonic and benthic fauna occurs, probably related to a period of lower sedimentation rates. Figure 16 illustrates the gamma-ray $\log$ response for parts of this borehole. The lower fan lobe shows a thinning-upward trend in the sand layers 
GAMMA-RAY WELL-LOG CHARACTERISTICS

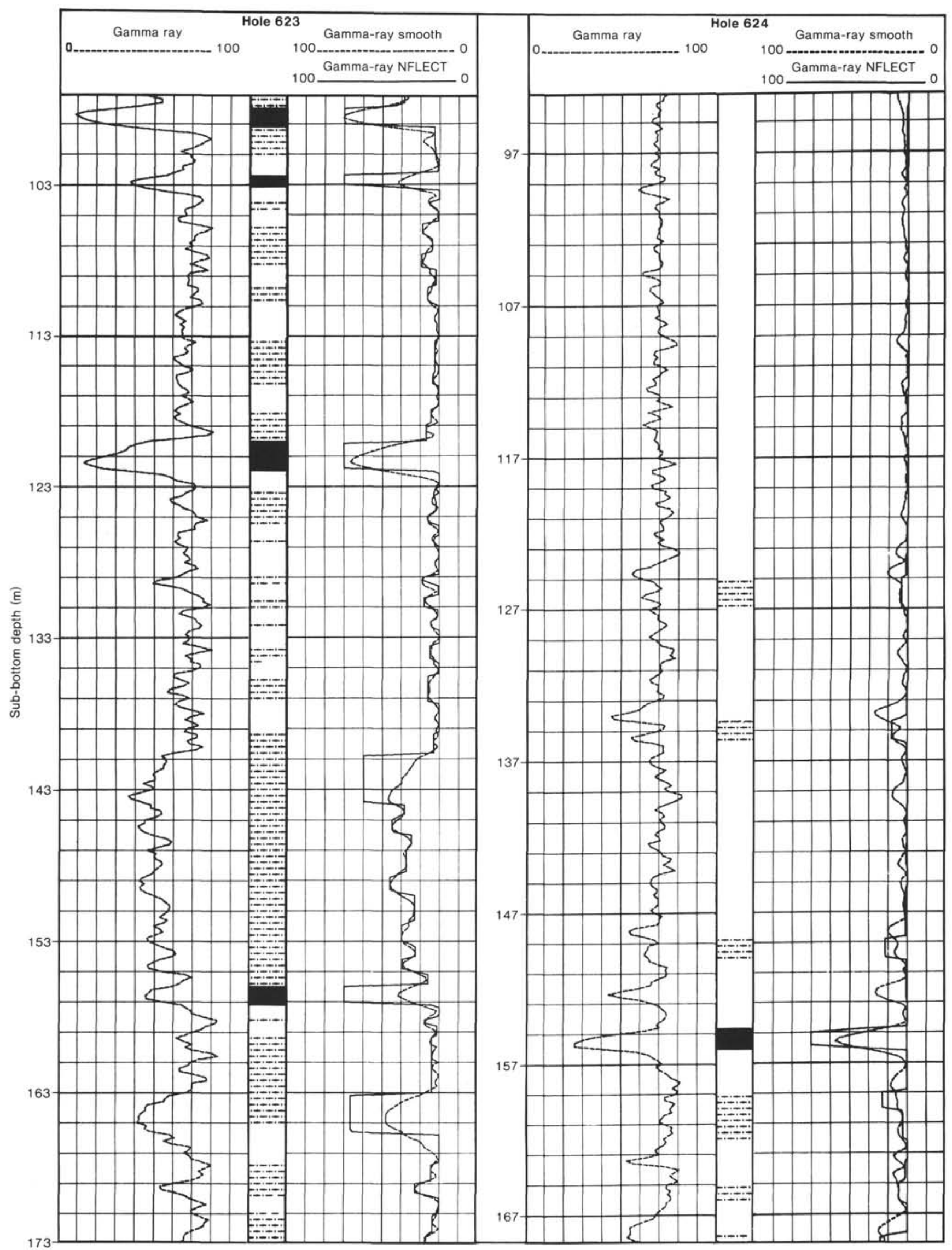

Figure 11. Gamma-ray and gamma-ray NFLECT curves for Sites 623 and 624. Key to lithology symbols is given in Figure 2. 

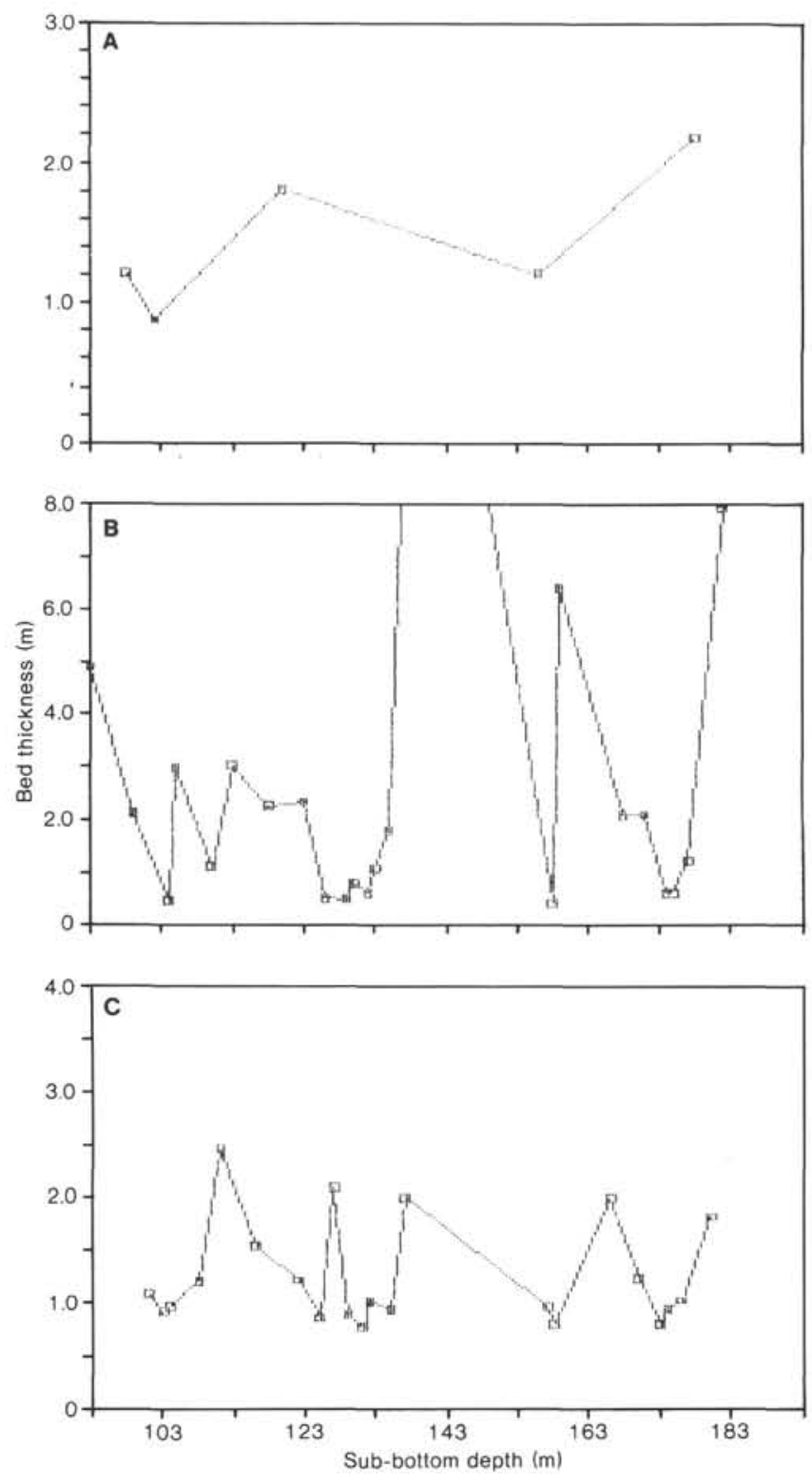

Figure 12. Bed thickness trends of (A) sand (NFLECT >70 API), (B) silt (NFLECT 70-20 API), and (C) clay (NFLECT <20 API) at Site 623.

(Fig. 17A) and alternating packages of thickening-upward silt beds, each package being from 20 to $50 \mathrm{~m}$ thick (Fig. 17B). The clay layers tend to show a crude thickening-upward trend, especially when evaluated on the thicker beds (Figure 17C). The sand beds average $1.27 \mathrm{~m}$ thick (SD 0.43), the silt beds average $2.77 \mathrm{~m}$ thick (SD 1.90), and the clay beds average $1.57 \mathrm{~m}$ thick (SD 0.82). Figure $18 \mathrm{~A}$ shows the grain-size trend, and the fining-upward trend is apparent.

The upper lobe, from the seafloor to a sub-bottom depth of $242 \mathrm{~m}$, contains less sand and overall is thicker bedded than the underlying fan lobe. The sand layers show little or no trend (Fig. 19A); the silt layers are quite thick and do not appear to display any trend (Fig. 19B), and the same is true of the clay layers (Fig. 19C). The

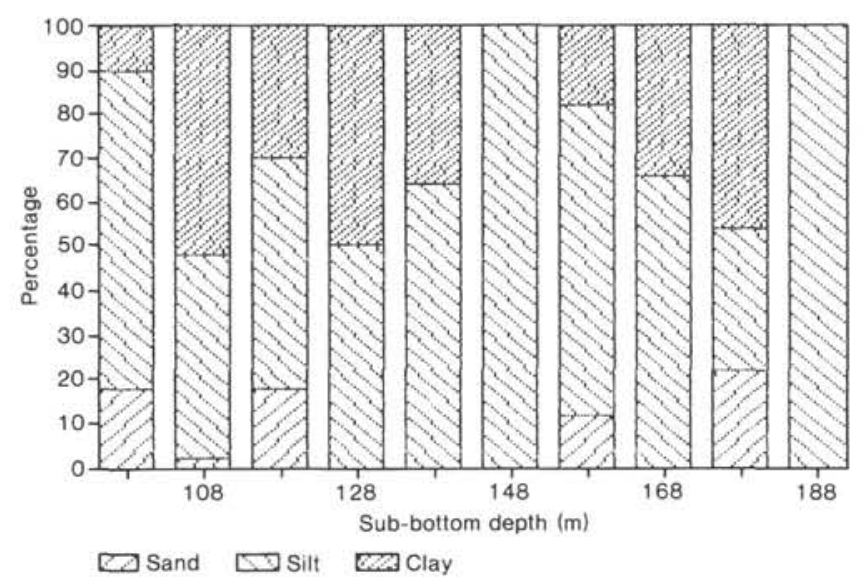

Figure 13. Sand-silt-clay percentages averaged over $10-\mathrm{m}$ increments at Site 623.

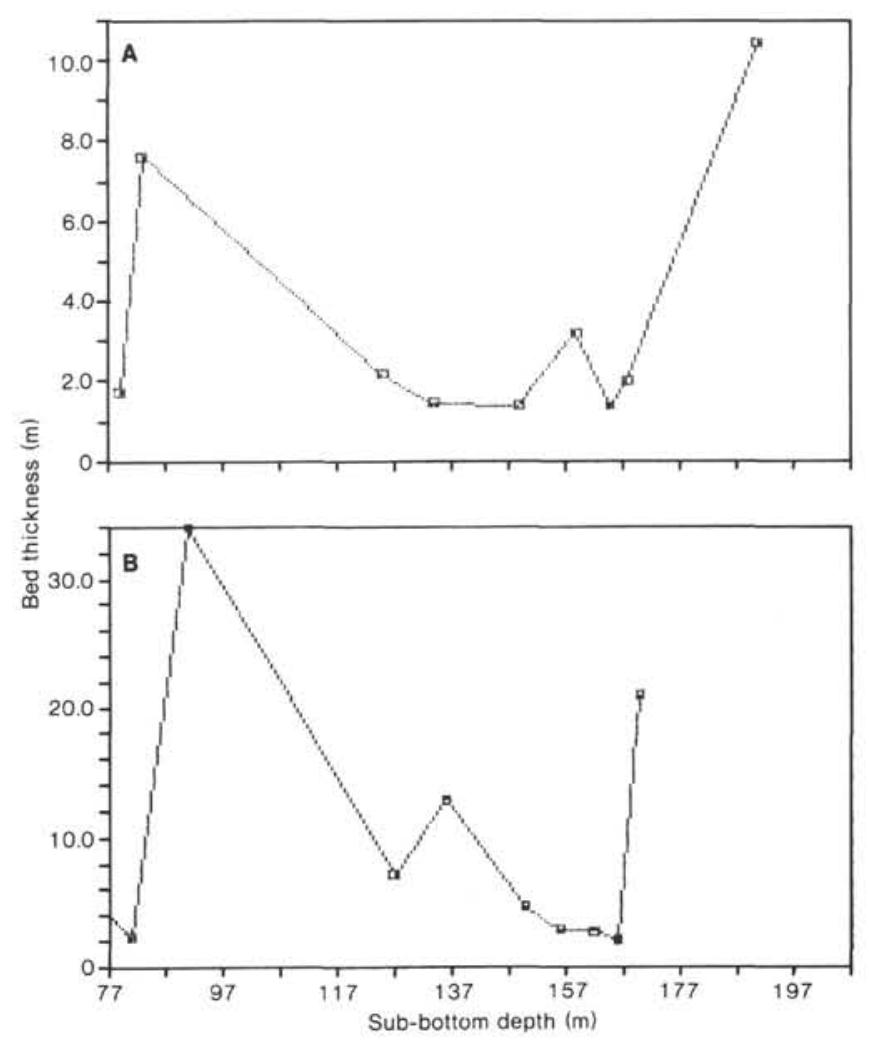

Figure 14. Bed thickness trends of (A) silt (NFLECT 70-20 API), and (B) clay (NFLECT <20 API) at Site 624.

sand beds average $1.03 \mathrm{~m}$ in thickness (SD 0.09), the silt beds average $3.40 \mathrm{~m}$ (SD 2.88), and the clay layers average $1.72 \mathrm{~m}$ (SD 2.21). A general fining-upward trend is suggested by the grain-size distribution (Fig. 19B), especially if the upper unlogged part of the borehole is examined.

The gamma-log response in this hole indicates that the sands are both underlain and overlain primarily by clays. The clay layers overlying the sands then grade upward into laminated silts, then into thinly laminated clays. This pattern is present in both fan lobes. 


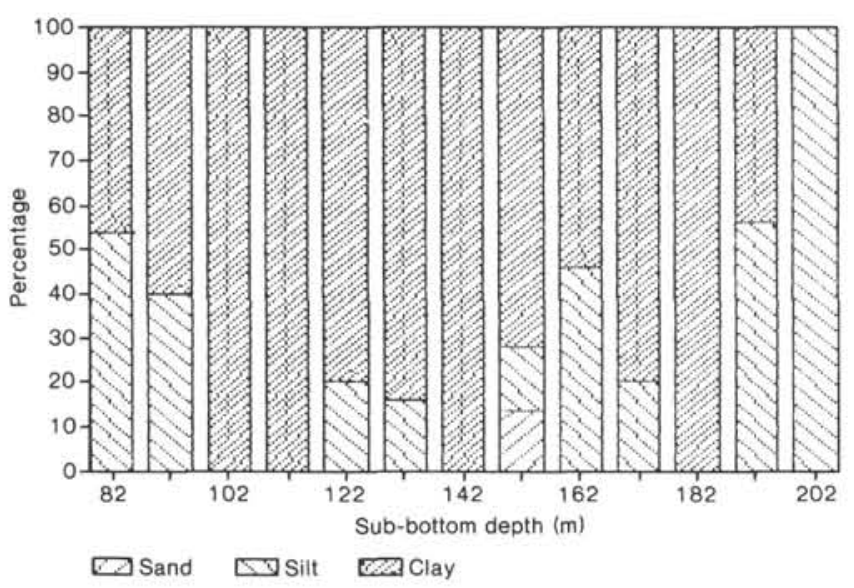

Figure 15. Sand-silt-clay percentages averaged over 10-m increments at Site 624.

\section{SUMMARY}

The well logs provide essential data in evaluation of the missing cored sections. Processed by the NFLECT program, they provide additional data on grain-size trends and bedding thickness in each logged hole. Figure 20 summarizes the sand-silt-clay percentages of each site. The channel sites in the midfan (Sites 621 and 622) and the lower fan channel site (Site 623) contain the highest percentages of sand. Of these three channel sites, Site 623 contains the highest percentage of sand. Site 623 contains the highest silt content and the least clay. The midfan overbank site (Site 620) contains some sand, but can be characterized primarily as a silt- and clay-rich sequence. The lower fan overbank site (Site 624) contains the highest percentage of clay and virtually no sand. The lower fan site (Site 615), at the distal ends of the channel system, contains less than $10 \%$ sand, but a very high percentage of silt.

\section{ACKNOWLEDGMENTS}

Appreciation is extended to Chevron USA, Inc., and Chevron Geosciences for providing the resources, both "hard" and "soft," for preparation of this study and for permission to publish the gamma-ray NFLECT displays. We acknowledge Phillip Sand Hansell II's assistance in providing interpretive computer-processed log displays and his help with the many details of the operation of the Chevron Rapid Well Log System. A draft version of this manuscript was reviewed by E. G. Wermund and R. Moiola.

\section{REFERENCES}

Asquith, G., and Gibson, C., 1982. Basic Well Log Analysis for Geologists: Tulsa (American Association of Petroleum Geologists).

Helander, D. B., 1983. Fundamentals of Formation Evaluation: Tulsa (Oil and Gas Consultants International Publications).

Roberts, H. H., and Thayer, P. L., 1985. Sedimentology of major depositional environments encountered in DSDP Log 96 borings. In Bouma, A. H., Normark, W. R., and Barnes, N. E. (Eds.), Submarine Fans and Related Turbidite Systems: New York (SpringerVerlag), pp. 331-339.

Schlumberger, 1972. Log Interpretation Manual/Principles (Vol. I): New York (Schlumberger Limited). 1974. Log Interpretation Manual/Applications (Vol. II): New York (Schlumberger Limited).

Date of Initial Receipt: 2 May 1985

Date of Acceptance: 5 July 1985 
J. M. COLEMAN, R. CONSTANS, A. H. BOUMA

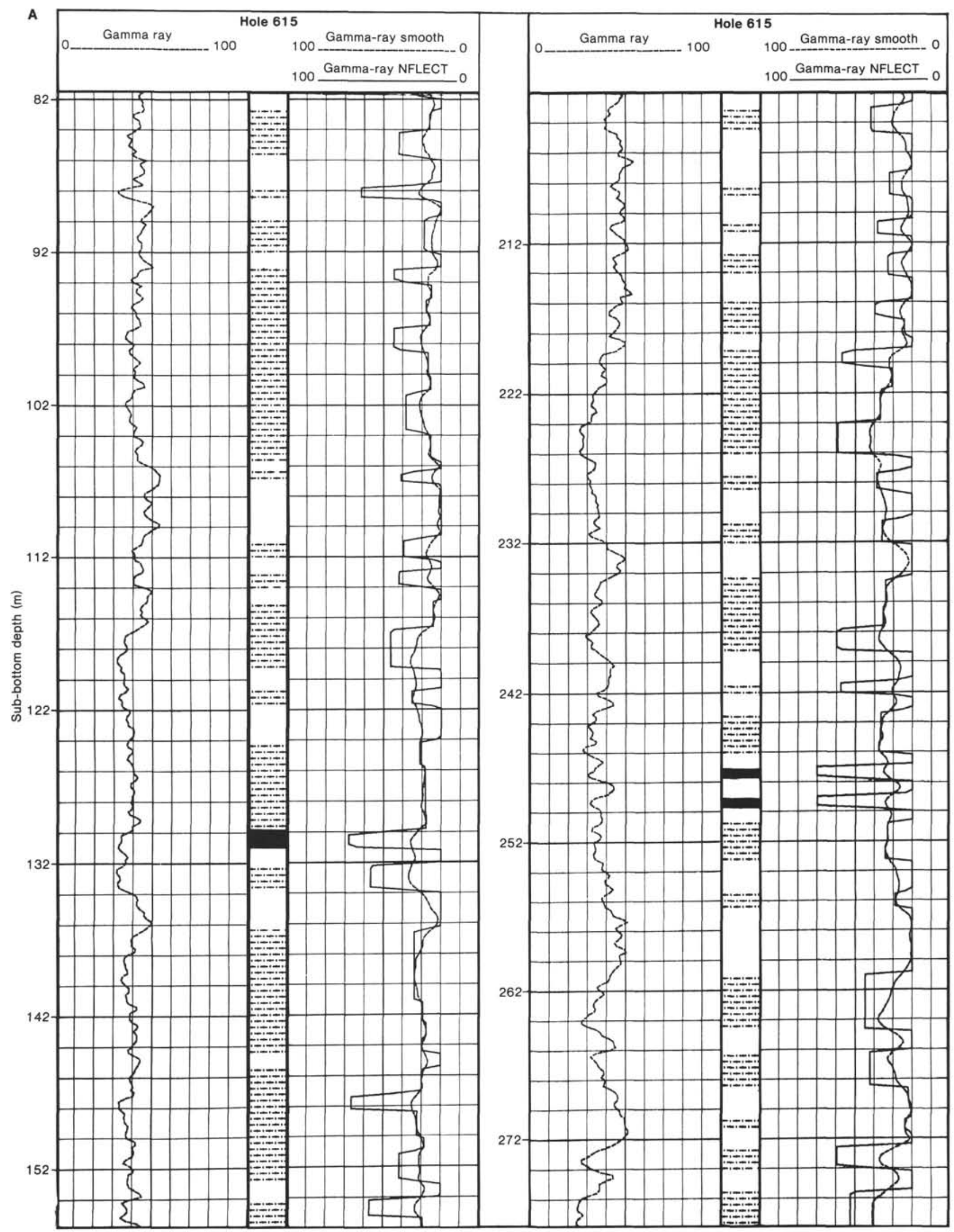

Figure 16. Gamma-ray and gamma-ray NFLECT curves for (A) upper and (B) lower parts of Site 615. Key to lithology symbols is given in Figure 2. 
GAMMA-RAY WELL-LOG CHARACTERISTICS

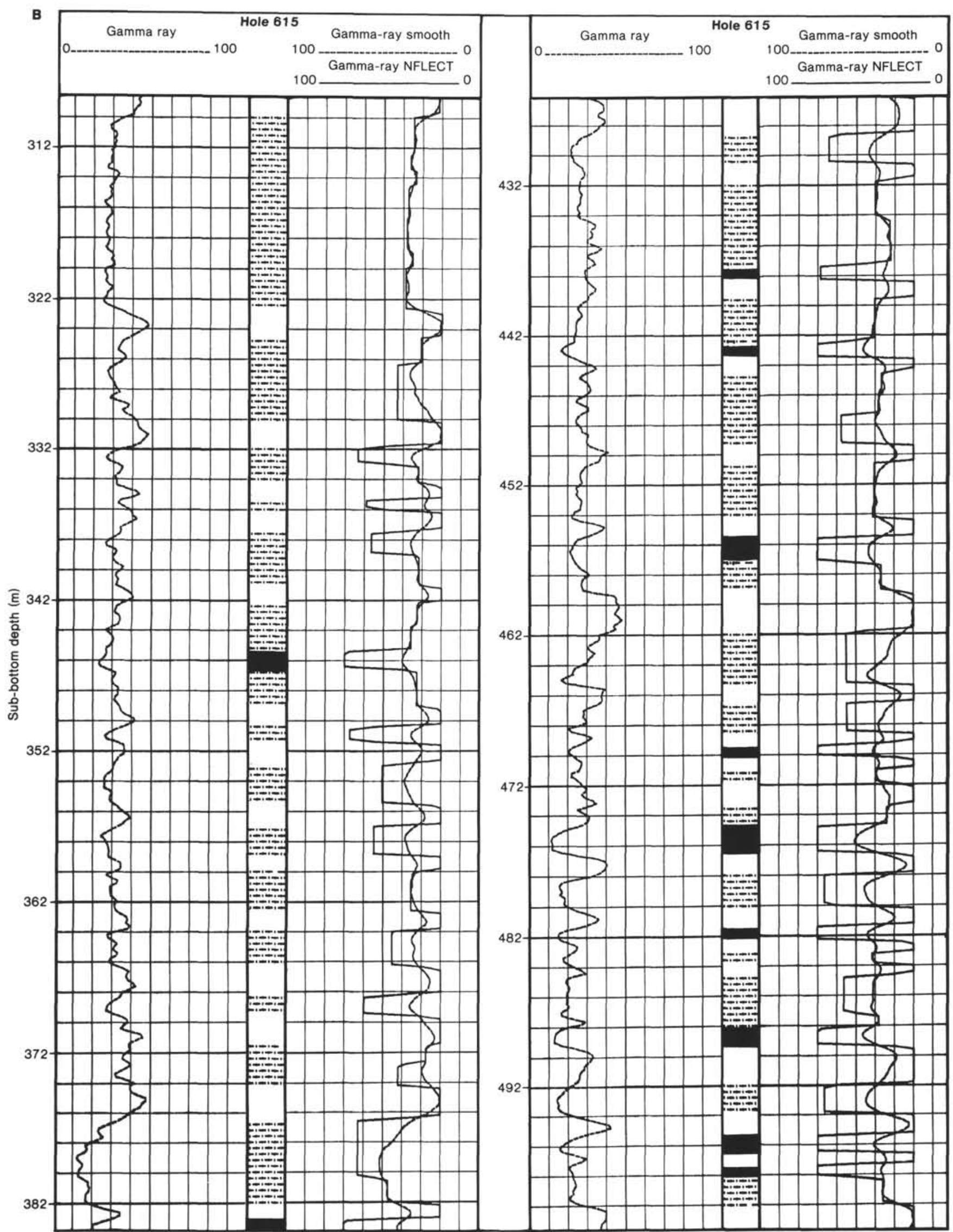

Figure 16 (continued). 

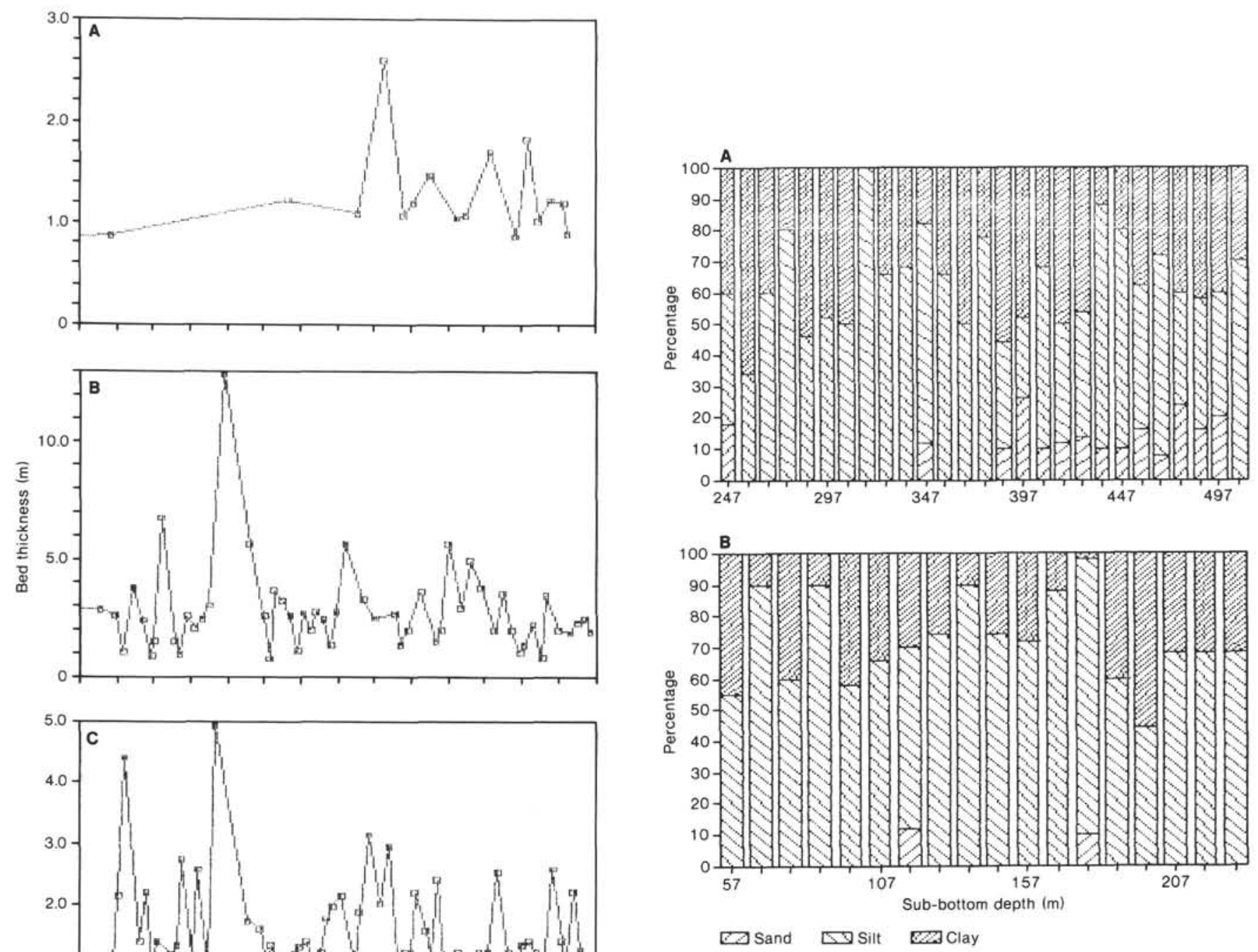

Figure 18. Sand-silt-clay percentages averaged over $10-\mathrm{m}$ increments for Site 615. (A) lower fan lobe, (B) upper fan lobe.

Figure 17. Bed thickness trends of (A) sand (NFLECT $>70$ API), (B) silt (NFLECT 70-20 API), and (C) clay (NFLECT <20 API) at the Site 615 lower fan lobe. 

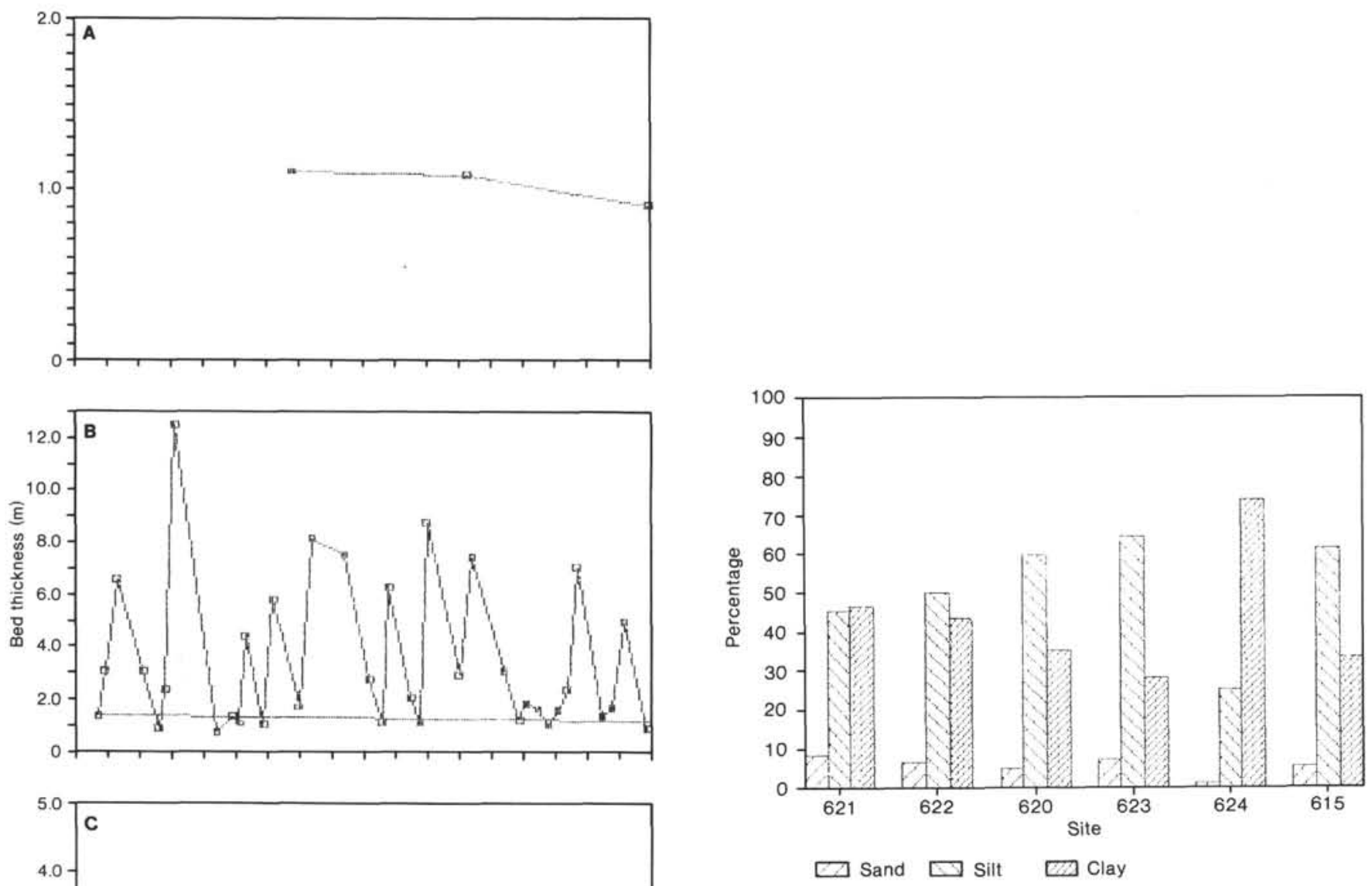

Figure 20. Total sand-silt-clay percentages for Leg 96 sites.

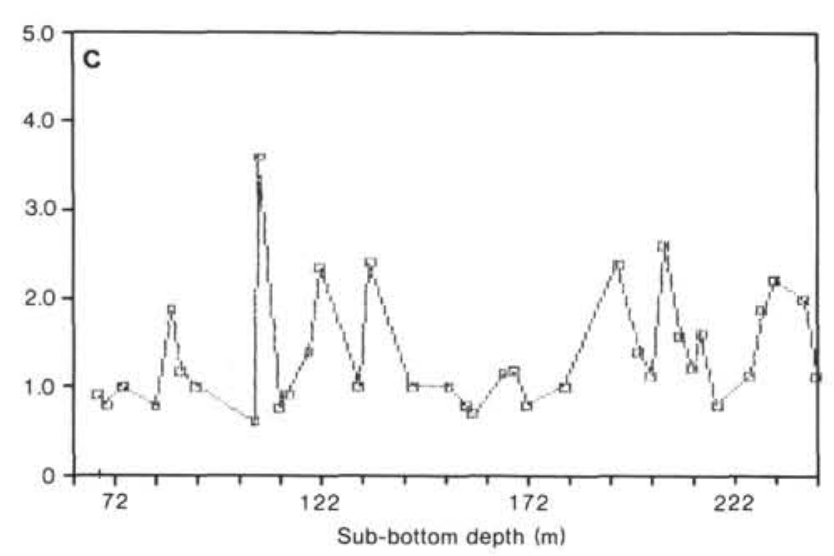

Figure 19. Bed thickness trends of (A) sand (NFLECT $>70$ API), (B) silt (NFLECT 70-20 API), and (C) clay (NFLECT $<20 \mathrm{API}$ ) at Site 615 , upper fan lobe. 